\title{
Discussion to the papers by G. Neale and A. M. Dawson
}

\author{
Chairman: Professor P. Fourman
}

\begin{abstract}
Chairman. I'd like to thank Dr Neale for drawing our attention to the important condition of chronic protein malnutrition and also to invite comment on Dr Dawson's paper. It is fashionable at the moment to link lactase deficiency which is now a 'none' disorder apparently with osteoporosis which we heard this afternoon is also a 'none' disorder. So we have positive correlation with two nonexisting conditions. Particularly striking is that the Negro has no lactase and osteoporosis, which doesn't exist anyway, certainly doesn't exist in the Negro.
\end{abstract}

MONTGOMERY. Could I ask Dr Neale if the adult kwashiorkor had fatty livers, was this shown in the biopsies?

NEALE. We only biopsied one patient's liver and there was a certain amount of increased fat in this liver but this wasn't until the patient had been treated with intravenous protein. These patients of course were all very sick and in fact they were not subjected to any biopsy procedures at all during the period when they were severely protein-depleted.

WATKINSON. Can you comment about the role of rotating antibiotics in these gastrectomy patients. Has this a place? Is this tried before protein feeding or after, or as a supplement?

NEALE. I think if a patient becomes very severely protein-malnourished it is probably correct to submit this patient to further surgery because he almost certainly has a blind loop, and it is almost certain to be a severe one. One of those nine patients, in fact, did have a blind loop, did refuse surgery and he was treated adequately with antibiotics for a period of about 18 months before he subsequently died of another condition.

Watkinson. Do you think it is of any value as a diagnostic test? If they improve on antibiotics that they have a blind loop?

NeALE. Yes, I think this is a fair statement that if they do improve on antibiotics then a loop is very likely. We found urinary indican the most valuable test here because the patients with this very severe pancreatic deficiency have no indican in their urine and this observation has also been made by Fortrand in the United States. Patients with blind loops, universally, have very high levels of indican in their urine so you can decide which of these two conditions is likely after partial gastrectomy.

WATKINSON The urinary indican I gather is not a terribly complicated test for a laboratory to undertake.

Neale. No, there is a simple test that one can do in the clinic and there is a more elaborate test which is very simple to do in the laboratory.

WATKINSON. If Dr Dawson gets a patient with one of these flat lactase curves, is one justified in putting him on a milk-free diet to see if he responds, is that how you assess the significance of this finding?

DAwson. I'm glad you raised that. I am sure some people do get better on milk-free diet, but unfortunately some people with functional diarrhoeas without alactasia get better too and probably would have with anything.
I must admit that there hasn't been an extensively controlled trial. These are especially people with severe diarrhoea. I think a lot of people with alactasia who have one or two softish stools a day do respond to this diet but the man with bowels open ten times a day, I haven't seen one of these respond to a milk-free diet. I think it is due to the sugar rather than some other agent.

Chairman. Can the intestinal flora digest your fancy lactulose?

Dawson. Yes it does.

HANCOCK. You said there was some relation between partial gastrectomy and pancreatic deficiency. How did you know they had pancreatic deficiency, firstly; secondly, do you have any observations about urinary indican after gastric surgery?

Neale. To answer the first question first, we knew that they had severe pancreatic deficiency because we measured the pancreatic enzymes from their small bowel on two occasions, and because they responded extremely well to pancreatic enzymes given orally, One of the patients had diabetes mellitus and was a known alcoholic. The other was not and we don't know why this patient had pancreatic insufficiency. The second question is have we measured urinary indican after partial gastrece tomy? The answer is yes, we have; it is raised in a pro portion of patients after partial gastrectomy, both after Bilroth I gastrectomy and Polya gastrectomy, and it does correlate moderately well with the number of $E$. coli in the small intestine of these patients. But you don't get the extremely high levels of urinary indican that you do with these patients with a frank stagnant loop syndrome.

HANCOCK. What proportion were high, of the gastrectomies you measured?

Neale. I can't give you an exact answer to this question, about $50 \%$ fall above our normal range but only perhaps just above it.

ChaIRman. Could I ask you, can you remember whether McCance's piglets had fused their epiphyses?

NeALE. There was severe abnormality in their bones and as far as I remember there was delayed fusion of epiphyses.

Chairman. They were fused?

Neale. Delayed fusion I think.

Chairman. Another question was do all patients with steatorrhoea who have a low serum albumin have protein malabsorption?

Neale. No. I tried to distinguish right at the very beginning that I wasn't going to talk about protein-losing enteropathy, and of course a lot of these patients with low serum proteins with malaborptive conditions do in fact have protein-losing enteropathy as the cause of their low proteins. Patients with protein-losing enteropathy don't have the general disturbances; they don't have the disturbances in liver function, disturbances in hair and skin growth-it is pure protein-losing enteropathy. 
Chairman. Yes, but what my question was trying to define was if you take both these recognized causes, we are still left, are we not with unexplained low pattern albumins in people with protein-losing enteropathy or other types of malabsorption?

Neale. Yes, the serum albumin though is usually not as severely reduced as in these patients in which case it is always less than $2 \cdot 5 \mathrm{~g}$.

Chairman. You don't have an explanation?

NeAle. I have not got an explanation, I don't know if anybody else here has.

Chairman. Well perhaps somebody has, because it it is a most intriguing question.

COMment. We've dealt with forty-four biopsies of partial gastrectomy and we've only found one low lactase activity. I quite agree with you that without controls the higher incidence of lactase deficiency among patients with gastrectomy has still to be shown.

Dawson. I think really this depends on your area, yours is probably much lower in your local population.

Comment. Yes, we've tried to arrange that we could screen their tubes so that we try to take the biopsies from the same area of the jejunum as in the normal controls.

Dawson. I'm sorry I didn't mean that, I mean the incidence of the alactasia of one in forty, let us say three to seventy at outside, it is probably a lot lower than other parts of the country. And this is why I think it is terribly difficult to ascribe lactase deficiency to a disease process.

Comment. We've got a family of Italians living here who also have very marked lactase deficiency and you say that this seems to be a recessive gene but they say that if they boil milk they take it quite alright, but as far as we can make out this does not affect the lactase level!

DAwSon. I would agree that this is why as I've said, I'm not terribly impressed that a milk-free diet is really doing anything.

Neale. I'd like to ask Dr Dawson, whether he has any experience with children with hypolactasia suffering from abdominal pain due to drinking milk? We've seen this three or four times now at Hammersmith. The child is forced to drink milk by the parents-you don't get a child necessarily with diarrhoea but with acute abdominal pain following milk ingestion.

Dawson. Yes, I have seen this.

BRACKENRIDGE. I wonder if there is any information on the adrenal cortical function in protein-calorie malnutrition. The reason I ask is I've seen very severe anorexia nervosa in a young man and to our surprise he had an extremely high plasma cortisol level. I wonder what happens in a straightfor ward protein-calorie malnutrition apart from that self-induced by fasting to death.

Neale. The answer to this question is that we have met plasma cortisols in two patients, in both patients they were elevated. It is well known now from work in the West Indies by Professor Waterlow's unit, that there is a disturbance in the handling of cortisol by the body and plasma cortisol levels do rise. 